\title{
Integrated Reporting In Shipping Industry: An Analysis of International Shipping Companies*
}

\section{Denizcilik İşletmelerinde Entegre Raporlama: Uluslararası Denizcilik Firmalarının Analizi}

\author{
Alperen Çıkıcç1 $^{1}$ ๑), Seçil Sigali² ${ }^{\circledR}$ \\ ${ }^{1}$ Graduate Student, Dokuz Eylül University Social Sciences Institute, İzmir, Turkey \\ ${ }^{2}$ Assoc. Prof., Dokuz Eylül University, Maritime Faculty, İzmir, Turkey \\ ORCID: A.C. 0000-0001-5429-5295; S.S. 0000-0002-5743-6169
}

\begin{abstract}
This study aims to analyze the compliance of shipping companies' financial and non-financial reports with the IIRC (International Integrated Reporting Council) integrated reporting framework. Integrated reports, annual reports, sustainability reports, and corporate social responsibility reports of international shipping companies issued and published between the years 2010-2018 were used as data. According to literature and the IIRC framework dimensions, content analysis and statistical tests were applied to create scores that show the compliance degree of the reports and companies. Consequently, the compliance score of the shipping companies shows a continuous rise within the sample period. The effect of the integrated reporting framework was examined by comparing the results before and after framework periods. Results show that the compliance scores of companies were significantly higher after the framework period.

Keywords: Integrated reporting, shipping companies, financial reporting, sustainability

ÖZ

Bu çalışma, denizcilik işletmelerinin finansal ve finansal olmayan raporlarının IIRC (Uluslararası Entegre Raporlama Konseyi) entegre raporlama çerçevesine uygunluğunu analiz etmeyi amaçlamaktadır. Veri seti, 2010-2018 yılları arasında hazırlanan ve yayımlanan uluslararası denizcilik işletmelerinin entegre raporları, yıllık raporları, sürdürülebilirlik raporları ve kurumsal sosyal sorumluluk raporlarını kapsamaktadır. Literatür ve IIRC kavramsal çerçeve boyutlarına göre, raporların ve işletmelerin uyum derecesini gösteren puanları oluşturmak için içerik analizi ve istatistiksel testler uygulanmıştır. Sonuçlar, denizcilik işletmelerinin uyum puanlarının örneklem dönemi içinde artan bir eğilim sergilediğini göstermektedir. Entegre raporlama çerçevesinin etkisi çerçeve öncesi ve çerçeve sonrası sonuçlarının karşılaştırılması ile ölçülmüştür. Sonuçlar işletmelerin uygunluk sonuçlarının çerçeve sonrası dönemde önemli ölçüde yüksek olduğunu göstermektedir.
\end{abstract}

Anahtar kelimeler: Entegre raporlama, denizcilik işletmeleri, finansal raporlama, sürüdürülebilirlik

*This study is a version of a master thesis titled as "Integrated Reporting In Shipping Industry: An Analysis of International Shipping Companies", Dokuz Eylül University Graduate School of Social Sciences, 2019.

Submitted/Başvuru: 22.01.2020 Accepted/ Kabul: 10.02.2020

Corresponding author/Sorumlu yazar/: Seçil Sigali / seçil.varan@deu.edu.tr

Citation/Atıf: Cikikci, A., \& Sigali, S. (2020). Integrated reporting in shipping industry: An analysis of international shipping companies. Muhasebe Enstitüsü Dergisi - Journal of Accounting Institute, 62, 23-35. https://doi.org/doi.org/10.26650/MED.2020 678485 


\section{Introduction}

Integrated reporting presents both financial and non-financial information of a company within a concise and single form to all stakeholders and has been creating a reasonable ground for sustainable growth for companies, thus for the global economy. Integrated reporting expedites to reach specific sustainable development goals by forming the business model of a company (Krzus, 2011: 275-276). Expected benefits of integrated reporting might be extended (Steyn, 2014: 479) as integrated reports serve as a key to address externalities issues in economic theory by reducing information asymmetry, providing more transparency, that leads to a higher financial and operational performance (Sigalı and Balsari, 2018).

Integrated reporting had an international call in 2010 by the establishment of the International Integrated Reporting Council (IIRC). The IIRC was established in order to gather different global parties to discuss and determine integrated reporting standards (IIRC, 2010a: 1). Benefits of the integrated reporting are also specified by the IIRC as "reported information better aligned with investor needs, higher levels of trust with key stakeholders, better resource allocation decisions including cost reductions, lower cost of, and better access to, capital because of improved disclosure" (IIRC, 2011: 21).

The first discussion paper was published by IIRC in 2011, with a single value creation model. Integrated reporting was defined at this discussion paper as (IIRC, 2011: 2): "Integrated Reporting brings together material information about an organization's strategy, governance, performance and prospects in a way that reflects the commercial, social and environmental context within which it operates. It provides a clear and concise representation of how an organization demonstrates stewardship and how it creates and sustains value". Although the discussion paper put forward new ideas on integrated reporting, the breakthrough principles and contents were determined by the IIRC in 2013 with the Integrated Reporting Framework. The integrated report was also defined by the IIRC at the International Integrated Reporting Framework as (IIRC, 2013: 7): "An integrated report is a concise communication about how an organization's strategy, governance, performance and prospects, in the context of its external environment, lead to the creation of value over the short, medium and long term".

An integrated report is prepared by an organization to reveal the integration of financial performance and non-financial organizational performance with its organizational vision. The integrated report also explains how an organization is going to approach that organizational vision (Abeysekera, 2013: 236).

The world population continues to grow, and shipping plays an essential role in the growth and sustainable development because it provides low-cost and efficient maritime transport. Maritime transport is the backbone of global trade and the global economy (Ki-Moon, 2016:1). Taking into account the significance of the shipping sector for the global economy, the benefits of integrated reporting would contribute to add value for a worldwide sustainable development, by presenting information on value created by the shipping firms, thus lowering information asymmetry. There is no research on the integrated reporting of shipping companies, as far as detected.

Therefore, this study aims to analyze the compliance of shipping companies' with the IIRC integrated reporting framework. The rest of the study is structured as follows: The second part reviews the literature, followed by data, methodology, findings, and the last part concludes the study.

\section{Literature Review}

Previous studies on integrated reporting have focused on various aspects. Studies that analyzed the financial performance aspects of the integrated reporting generally focused on its effect on the share price of the organization and the cost of capital. On the other hand, some of the studies examine the accounting and auditing practices of integrated reporting. The primary motivation of these researches is to demonstrate the current situation of integrated reporting.

Atkins and Maroun (2015) analyze initial reactions of the South African institutional investment community to first sets of integrated reporting according to the data of 20 experts from the South African institutional investment industry. Integrated reporting is seen as an improvement on traditional reporting. However, findings reveal that the length of the reports and 
repetition tort usefulness of report (Atkins and Maroun, 2015: 215). For further research, they suggest that the disclosures and the structure of the integrated reports may be analyzed (Atkins and Maroun, 2015: 215). Abeysekera (2013) searches for an appropriate template for an integrated report. Abeysekera (2013) uses King Reports of South Africa and publication of the IIRC as data and it proposes that integrated reporting should explain the vision and values of an organization. The organization should use facets of resources as financial, intellectual, social and environmental. For further research, influence of the various capitals organizational to performance and reports of the organization might be searched (Abeysekera, 2013: 244). Chang et al. (2014) argue that financial capital providers are too dependent on short term returns while integrated reporting proposes a new thinking model and actions. For future research, performance metrics, organizational disclosure, and connection of core business activities with environmental, social and governance matters might be examined (Cheng et al, 2014:101). Bommel (2014) conducts a research to find out the resolution of impediments in the integrated reporting process. Bommel (2014) obtained data through 64 in-depth, semi-structured interviews with relevant managers and actors. According to the results of the study, integrated reporting should focus on industrial, environmental and social matters. Examination of different samples to understand the structure of integrated reports might be analyzed for the future (Bommel, 2014:1182). Villiers et al. (2014) examines the synthesis of the accounting and accountability research for integrated reporting. Previous studies on integrated reporting are used as data. Their findings show that there is rapid development in integrated reporting policy but the development of practices is not rapid. More academic research is needed to guide the conjunction of policy, practice, and execution of the integrated reporting guidelines (Villiers et al, 2014: 1052). Stubbs and Higgins (2014) investigate the internal working mechanism of integrated reporting in Australia. 23 interviews with executives of the 15 different organizations are used as data (Stubbs and Higgins, 2014:1068). According to Stubbsand Higgings (2014), integrated reporting changes reporting processes and structures, however, does not bring a significant shift in company disclosure (Stubbs and Higgins, 2014:1068). Yllmaz (2016) evaluates integrated reports in terms of quality of information, content, and presentation. According to the conclusion of the study, the importance attached to the trustworthiness of the information quality varies from sector to sector (Yllmaz, 2016: 104). Kurochkina et al (2017) use content analysis and show that integrated reporting standards should be universal and feasible to all kinds of activities including transport and communication enterprises (Kurochkina et al, 2017: 276). Maroun (2017) offers qualitative and quantitative measure issues to be studied to ensure the reliability of interpretatively formed integrated reports (Maroun, 2017: 344). According to Maroun and Atkins (2018), policies, plans and actions should address the different types of capital to be effective (Maroun and Atkins, 2018:116). Şimşek (2018) presents empirical evidence from Turkish companies. 2016 integrated reports of 5 companies are used as data and analyzed with the content analysis method. Findings of the research show that in spite of deficiencies in reports, actions are encouraging for the future. However, a higher number of organizations should practice integrated reporting (Şimşek, 2018: 119). Oral (2018) examines the perspectives of integrated reporting. 50 integrated reports of the various firm were used as data. Content analysis of each report was made (Oral, 2018: 36). Every business specifies its own business model at the report. Jensen and Berg (2012) find that integrated reporting is more likely used in countries where higher investor protection is active. Traditional sustainability reporting more likely exists where trade unions' impact is high (Jensen and Berg, 2012: 312). Stent and Dowler (2015) examine the compliance of reports with integrated reporting requirements in New Zealand and develop a checklist to find out the compliance of the reports (Stent and Dowler, 2015: 92). According to the findings of Stent and Dowler (2015), existing reporting procedures cannot dispose of future uncertainties. These deficiencies may lead to financial crisis and harm sustainability (Stent and Dowler, 2015: 92). Evaluation of reports to measure its compliance with the integrated reporting framework is a significant area for further research (Stent and Dowler, 2015: 114).

However, although many researchers (Brown and Dillard 2014, De Villiers 2014, Stubbs and Higgins 2014, Havlovaa 2015, Yllmaz 2016) point out the necessity of using more different samples with more sectoral evidence, no evidence is detected on the shipping companies as far as detected, thus this creates the primary motivation of this research. Examination of the shipping firms and their reports in terms of compliance degree with the integrated reporting framework may be studied. The primary purpose of this research is to evaluate the shipping firms and their reports with respect to compliance with the integrated reporting framework. In this study, shipping companies' reports were used as data to determine the current and retrospective situation of compliance. 


\section{Research Sample}

Shipping companies that issued integrated reports between the years 2010-2018 were investigated from IIRC database. 2 companies as Mitsui OSK Lines and Nippon Yusen Kaisha Lines reports are exerted from the IIRC database. Shipping companies that issued sustainability or corporate social responsibility reports between the years 2010-2018 according to the one of the GRI Sustainability Guidelines version 4, version 3. 1 and version 3.0 were investigated from the GRI database. China Cosco Holding, Kawasaki Kisen Kaisha Lines, Evergreen, Wan Hai Lines and Panalpina were found from the GRI database. The global top 30 container lines were analyzed in the review of the maritime transport report (UNCTAD, 2018: 32). Three of the companies in the sample are in the global top 30 container lines. China ocean shipping company is fourth, Evergreeen is seventh and and Wan Hai lines is thirteenth in the top 30 global container lines in the "review of the maritime transport" 2018 report (UNCTAD, 2018: 32). Other companies that are in the global top 30 container lines are not available in the IIRC and GRI databases. More detailed information on the sample may be found in table 10 to table 18 . Mitsui OSK Lines is one of the three Japanese shipping firms, and issued corporate sustainability reports from 2010 to 2017 together with the annual reports. The company started to publish an integrated report and a corporate sustainability report in a single form for 2018. The company used version 3.0, 3.1 and 4 of the GRI sustainability guidelines in the previous years. Reports involve information on safe operation, financial data, management, environment, and society. Financial information was audited by the KPMG. NYK line is one of the three Japanese shipping lines and one of the two international integrated reporting council members with MOL. NYK Lines has been issuing integrated reports since 2013. NYK Lines financial information was audited by the independent audit firm Deloitte. China Cosco Holding is one of the Chinese shipping organizations. This company issued sustainability reports according to the global reporting initiative guideline version 3.1. for the years 2013 and 2014. Although there are sustainability reports issued in the following years, there is no reference of them in the international guidelines for the years 2011-2012 and 2013. Accuracy of the financial information has been audited by the PWC. The annual report of 2018 has not been issued yet. Kawasaki Kisen Kaisha Lines is the last Japanese company which took place in the data set. K-line has been revealing integrated reports since 2014. K-Line published yearly sustainability reports between the years 2010 and 2013 according to the GRI Guidelines version 3. 0 and version 3. 1. The financial information was audited by the Ernst and Young. Evergreen is a Taiwanese firm. Evergreen issued corporate social responsibility reports for the years 2014, 2015 and 2016 in addition to their annual reports. Reference guideline of sustainability reports is the GRI guideline version 4. 0. However, there are no corporate social responsibility reports in the following years. The financial information was audited by the PWC. The annual report of 2018 has not been released yet. Wan Hai Lines is another Taiwanese firm. Wan Hai Lines has been issuing sustainability reports since 2014 according to the GRI Guidelines version 4. The annual report nor the sustainability report of 2018 has been issued yet. All of the financial statements were audited by the KPMG.

Panalpina is a Swiss company and issued integrated reports for the years 2016 and 2017. Integrated reports of 2016 and 2017 not only inform stakeholders financially but also provide insight related to the business model and strategic directions of the firm.Eighty-four reports that belong to these seven international shipping companies were analyzed for the period of 2010-2018.

\begin{tabular}{|l|c|c|c|c|c|c|c|c|c|}
\hline Table 1: Distribution of Reports According to Years and Categories \\
\hline Categories & $\mathbf{2 0 1 0}$ & $\mathbf{2 0 1 1}$ & $\mathbf{2 0 1 2}$ & $\mathbf{2 0 1 3}$ & $\mathbf{2 0 1 4}$ & $\mathbf{2 0 1 5}$ & $\mathbf{2 0 1 6}$ & $\mathbf{2 0 1 7}$ & $\mathbf{2 0 1 8}$ \\
\hline Annual Report & 7 & 7 & 7 & 6 & 5 & 5 & 4 & 4 & 0 \\
\hline Integrated Report & 0 & 0 & 0 & 1 & 2 & 2 & 3 & 3 & 3 \\
\hline SR and CSR & 2 & 3 & 2 & 4 & 5 & 4 & 3 & 2 & 0 \\
\hline $\begin{array}{l}\text { Total Number of } \\
\text { Reports Per Year }\end{array}$ & 9 & 10 & 9 & 11 & 12 & 11 & 10 & 9 & 3 \\
\hline
\end{tabular}

Source: Processed by the Authors SR: Sustainability Report, CSR: Corporate Social Responsibility Report

Table 1 shows the distribution of reports by categories and years. Except for 2018, minimum 9 and maximum 12 reports 
were used for each year. There are only three reports for the year 2018. Reports used as data consists of annual reports, integrated reports, sustainability report, and corporate social responsibility report. Only MOL, NYK Lines, and K Lines issued their reports for 2018. Results relying on 2018 reports were ignored so as to prevent any misinterpretation of results. Data set consists of forty-five annual reports, fourteen integrated reports, and twenty-five sustainability or corporate social responsibility report which sum equals eighty-four reports.

\section{Research Method of the Study}

In order to examine the compliance of the shipping companies' reports with the integrated reporting framework, content analysis was used. Stent and Dowler (2015) examines the compliance degree of corporate reports with the integrated reporting framework. For this purpose, they created a checklist that is going to be used for measurement (Stent and Dowler, 2015: 92). First, the checklist was created and developed according to the prototype integrated reporting framework (IIRC, 2012). However, the checklist was amended according to the integrated reporting framework (IIRC, 2013). There are some new regroupings within the final version of the (IIRC, 2013) integrated reporting framework (Stent and Dowler, 2015: 103). The checklist by Stent and Dowler (2015: 104-106) was used to measure the compliance of the data with the integrated reporting framework. The sample by Stent and Dowler consists of four organizations. There are seven primary categories in the checklist. These categories were created according to the content elements of the international integrated reporting framework. The first is the "organizational overview and business model", the majority of the elements under this category are self-explanatory (Stent and Dowler, 2015: 107). The second is the "Operating context" that was created so as to measure the disclosures on the explanation of the external environment in which companies operate (Stent and Dowler, 2015: 107). The first and second categories correspond to the "organizational overview and external environment" and the "business model" (IIRC, 2013: 24-25) in the IIRC integrated reporting framework.

The third is the "strategic objectives and strategies to achieve them". This category measures the setting of objectives and the relationship of the strategies with the operating context. This category comes up to the "Strategy and resource allocation" (IIRC, 2013: 27) in the IIRC integrated reporting framework. The fourth is the "governance" category. It is used to examine the operation structure and the decision-making process of the companies. Things under this heading are vital for the stakeholder relationship. "Governance" exists as a content element in the integrated reporting framework (IIRC, 2013: 25). The fifth is the "performance category" as in the integrated reporting framework (IIRC, 2013: 28). The maximum score for the performance category is ten points. The presentation of the information related to performance is examined under this heading (Stent and Dowler, 2015: 107).The sixth is the "Future Outlook" which was created to assess the disclosure of companies' opportunities, uncertainties, challenges and external factors (Stent and Dowler, 2015: 107). This category was created to correspond to the "Outlook" in the integrated reporting framework (IIRC, 2013: 28). "Assurance" was specifically created to present whether reports are externally audited or not. The maximum score according to that Checklist is equal to fifty-three points.

\section{Findings}

The checklist by Stent and Dowler (2015: 104-106) was applied to all of the reports. The score was shown according to checklist categories and years. The total score of every company for the same year and the score of the firms for the same category and for the same year were totaled. Since only Mitsui OSK Lines, Kawasaki Kisen Kaisha Lines, and Nippon Yusen Kaisha Lines issued their 2018 reports, the results of 2018 are ignored to prevent any misinterpretation.

\subsection{Organizational Overview and Business Model}

In this category, disclosures regarding the organization and business model are examined. This category corresponds to "organizational overview and external environment" and "business model" in the integrated reporting framework (IIRC, 2013: 24-25). Availability of mission and vision statements, value and culture of their operations then ownership and operating structure of the firm were analyzed. Companies generally explain their operations, services or products. Reporting boundary refers generally scope of the report or reporting process. Results are presented in Figure 1: 


\section{Organisational Overview and Business Model}

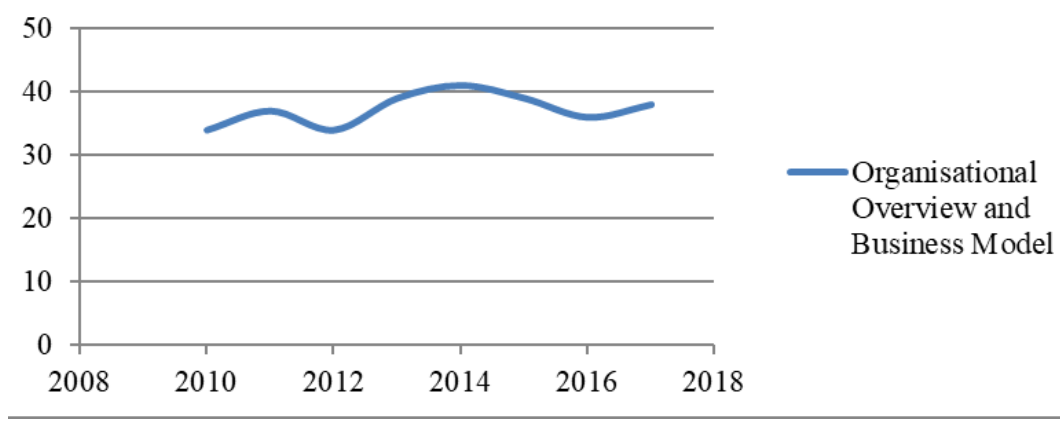

Figure 1. Results for the Organisational Overview and Business Model

According to the checklist, the highest score may be nine for this category and the total score of the seven shipping companies for a year is sixty-three points. However, the aggregated score is between thirty and forty points. The scores obtained from this category from 2010 to 2017 are respectively: 38, 42, 39, 44, 46, 43, 42 and 44 points. Scores of 2011, 2013, 2014 and 2017 showed increases. The lack of explanation about mission, vision and reporting boundary caused three declines in the years 2012, 2015 and 2016. Companies do not explain mission, vision and reporting boundaries for every year.

\subsection{Operating Context}

This category is relatable to the "organizational overview and external environment" (IIRC, 2013: 24) that is a content element in the integrated reporting framework. In this category legal, commercial, social, environmental and political conditions are expected to be defined. For every explained condition, one point is given. If companies define all of their legal, commercial social, environmental and political conditions in which they operate, five points were given. Recognition of key risks and opportunities and the materiality determination process is investigated for this category. Figure 2 shows the operating context score of seven firms between the years 2010-2017. According to the Stent and Dowler (2015) Checklist, the maximum score of a shipping firm for operating context may be nine points for a year. Pursuant thereto the highest total score of seven shipping firms may be sixty-three points for a year. However, the total score of seven shipping firms from this category is generally between forty and fifty points per year. The Governance category scores between the years 2010 and 2017 were, respectively $39,41,40,44,52,47,48$ and 49 points. The primary reason for the decline in 2016 was that some companies abstained from the explanation of the political environment and risk which may influence their operations. Shipping companies generally explain their risk management. From the years 2010 to 2013, the annual score has not changed much. The score has risen in the year 2014, then fell again in 2015. The scores for the years 2016 and 2017 have remained close to each other.

\section{Operating Context}

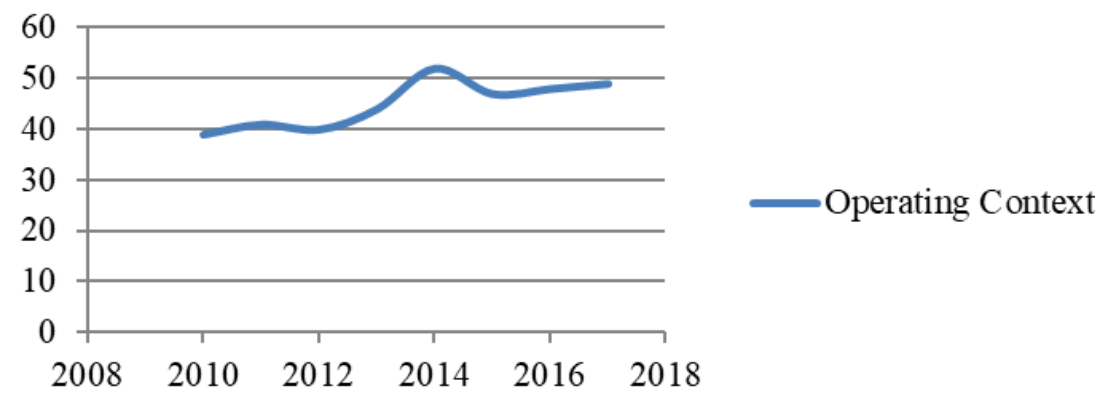

Figure 2. Results for the Operating Context

\subsection{Strategic Objectives and Strategies to Achieve Them}

In this category, the specification of objectives according to their time spam, determination and implementation of the plan, and companies' effects on capitals and risks were scored. According to the Stent and Dowler (2015) checklist, the 
highest score may be eight points for a year for this category. This category was created to correspond to "strategy and resource allocation" (IIRC, 2013: 27), that is a content element in the integrated reporting framework.

Strategic Objectives and Strategies to Achieve Them

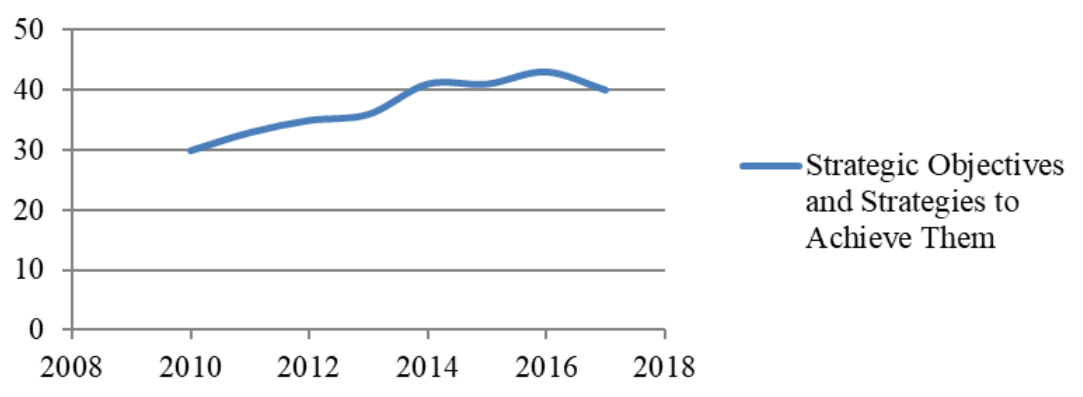

Figure 3. Results for the Strategic Objectives and Strategies to Achieve Them

According to the Stent and Dowler (2015) checklist, the highest score of the total of seven shipping firms may be fifty-six points for a year. On the other hand, the total of the score is between thirty and forty points for a year. The scores for this category between 2010 and 2017 are shown respectively as follows: 30, 33, 35, 36, 41, 41, 43 and 40 points. There is an uptrend in the score between the years 2010-2016. However, the scores of the companies decreased in 2017. The decline of the score in 2017 is subject to a set of reason. One of them is that companies generally specify their objectives but they are not classified in terms of time span. Even though organizations include stakeholders in the decision making the process, there is no intensive participation of stakeholders in the formulation of the strategies.

\subsection{Governance}

In this category, various features of governance related to integrated reporting were analyzed. The explanation of company executives with their skills and experience was evaluated according to explanation detail. "Governance" exists as a content element in the integrated reporting framework (IIRC, 2013: 25). In addition to that, monitoring systems for the implementation of strategies and the effect of organizational culture at the relationship with stakeholders were observed.

"Compensation policies and plans" and "integrated reporting process" were taken into consideration in the scoring. According to the Stent and Dowler (2015) checklist, the highest score for this category is eight points. In that sense, the highest score of seven companies from this category may be fifty-six points. However, the score is generally between twenty and forty points for the years 2010-2017. The scores obtained from this category between the years 2010 and 2017 are respectively $23,25,27,29,33,36,35$ and 35 points.

The governance score rises continuously from 2010 to the 2015 year. However, the score decreased in the year 2016 and remained stable in 2017. The reflection of organizational culture in communication with stakeholders is not directly expressed for each year.

\section{Governance}

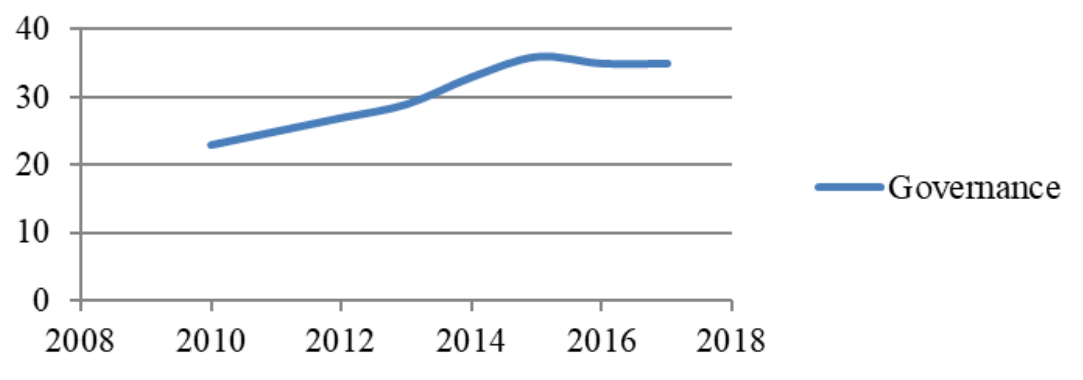

Figure 4. Results for the Governance 
Companies listed their executives in their reports but some of them did not explain their skills and the experience. Compensation of executives and annual minimum increase rate for salary are determined at the reports. However, there is no elaborate information about compensation policies and plans. There are no disclosures that present the integrated reporting process of the company.

\subsection{Performance}

In this category of the Stent and Dowler (2015) checklist, the highest point may be ten a year for a company. The "performance" also exists as a content element (IIRC, 2013: 28) in the integrated reporting framework.

\section{Performance}

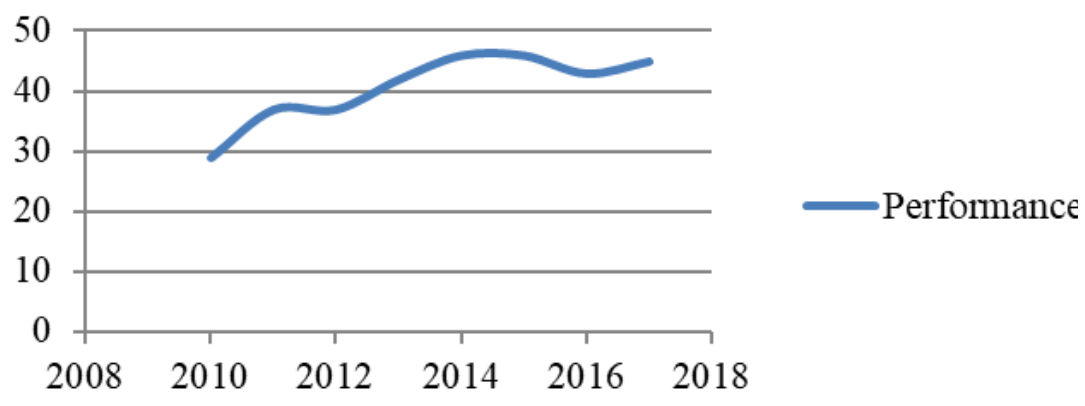

Figure 5. Results for the Performance

The availability of key performance indicators and the key risk indicators in the reports are investigated. In addition to that, the "setting of regional or industrial benchmarks" and "comparisons of actual and targeted results" were questioned. The highest score of seven companies from this category might be seventy points for a year. From 2010 to the year 2017, the scores for the performance category are respectively 29, 37, 37, 42, 46, 46, 43 and 45. In the period of 2010 and 2014 scores increased. The score of the year 2015 year has remained the same and the score decreased for 2016. However, the score of the year 2017 year has risen again. Regional and/or sectoral benchmarks generally were not set in the reports. There are few comparisons of actual and targeted results in the reports. The majority of the reports have statements regarding the stakeholders, but they do not have statements describing key stakeholder relationships.

\subsection{Future Outlook}

The future outlook category examines the readiness of the companies for forthcoming events and their compliance with the integrated reporting framework. This category was created to correspond to the "Outlook" content element (IIRC, 2013: 28). According to the Stent and Dowler (2015) checklist, the highest score for this category may be six points. The highest score for the total of seven companies may be forty-two points. Between the years 2010-2017, scores received respectively are 26, 26, 28, 30, 32, 31, 31 and 32 points. From 2010 to 2014, the score has been showing an increase. Although the score for the years 2015 and 2016 show a little decrease, and in 2017, the score rises again. The availability of the management's expectation on future operations and uncertainties that lead to risk were examined. Scores decrease due to a lack of some explanation. For example, there is no explanation about the "extreme consequences associated with real risks". Even though the expectations of executives are available in the reports, and this increases the scores, potential implications are not available, and this decreases the score. The statement of "key assumptions" and "probable risks" was explained in the reports and these increased the score obtained for this category. 


\section{Future Outlook}

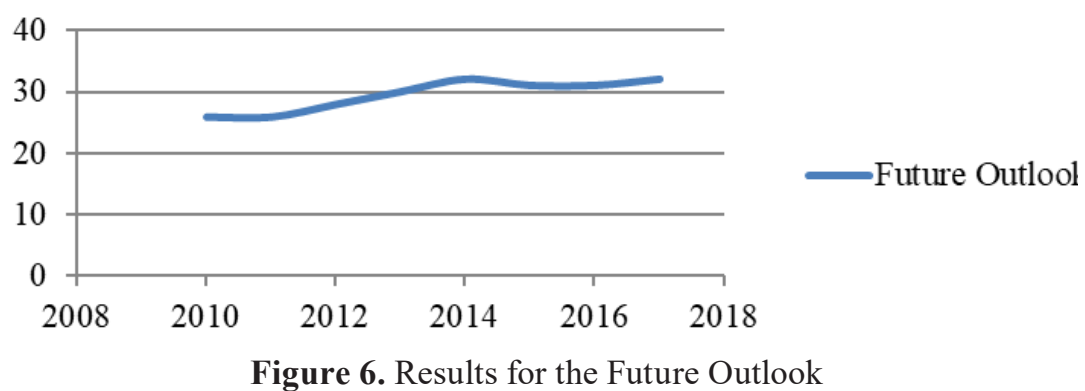

\subsection{Assurance}

The "Assurance" category of the Stent and Dowler (2015) checklist also exists in the content of the integrated reporting prototype framework (IIRC, 2012: 46). If there is "no assurance" or "only mandatory audit" they are respectively equal to 0 and 1 point. If only financial statements were audited by independent auditors and disseminated to the public, it is equal to 2 points. The addition to the audit of financial information, non-financial information audited by the independent real or legal persons, equals 3 points.

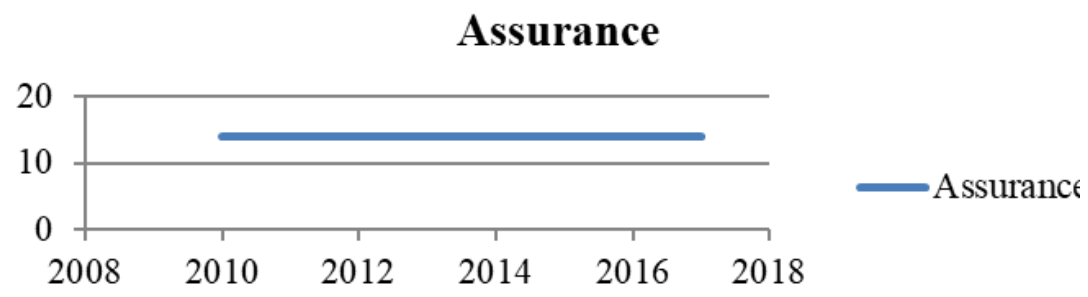

Figure 7. Results for the Assurance

Financial statements of the seven companies were audited by international independent audit firms for every year. However, there was no explanation about the audit of the non-financial information, and then, no company took three points from the "assurance" category.

\subsection{Total Score of Companies}

According to the Stent and Dowler (2015) checklist, the highest score may be fifty-three points for a company and the highest total score of seven companies for a year may be three hundred seventy-one points. Figure 8 shows the total score of the companies in the data. So, as to measure the compliance of reports with the integrated reporting framework, the total score should be analyzed for every year. The total score of companies between the years 2010 and 2017 are respectively 196, 215, 217, 239, 266, 264, 261 and 264 points. From 2010 to the year 2014, the total score shows an increase. However, the total score decreases in the years 2015 and 2016, and the total score rises again in the year 2017.

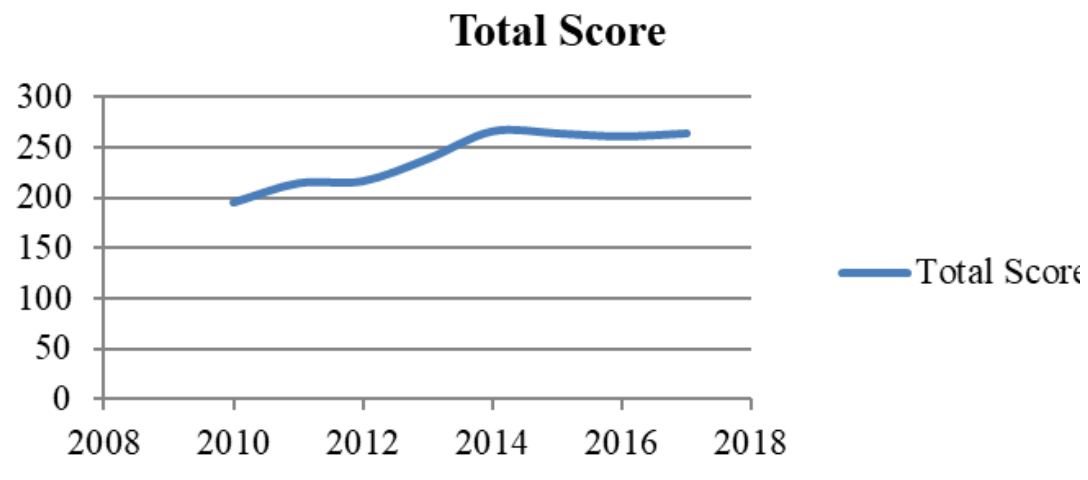

Figure 8. Total Score of the Companies 
When the score of the years 2014, 2015, 2016 and 2017 is compared, a huge difference is not available. The primary reason for small declines in 2015 and 2016 may be efforts by the companies to make reports concise. This prevents a detailed explanation of all the information about the company.

\subsection{Ranking and Dependent $T$-Test of the Companies}

In order to examine the influence of the integrated reporting framework on the score of firms, paired samples t-test was applied to the data. Table 2 shows the t-test results of the firms. The total score of the years 2010-2013 was summed up with each other. The total score of the years 2014-2017 was summed up with each other. The Before Framework refers to the total of the score between the years 2010-2013. The After Framework refers to the total of the score between the years 2014-2017. The total score of the before framework years and the after framework years were compared with each other. The alteration also needed to be examined in terms of the checklist categories. The score of the categories was compared to determine changes before and after the framework. The primary aim is to demonstrate the influence of the integrated reporting framework on the score of the reports. The T-test result of the "organizational overview and business model" category is 0.325. This means the integrated reporting framework has not influenced the "organizational overview and business model" category score of the corporate reports. The zero hypothesis for the "operating context" is that the integrated reporting framework has not influenced the operating context score of companies.

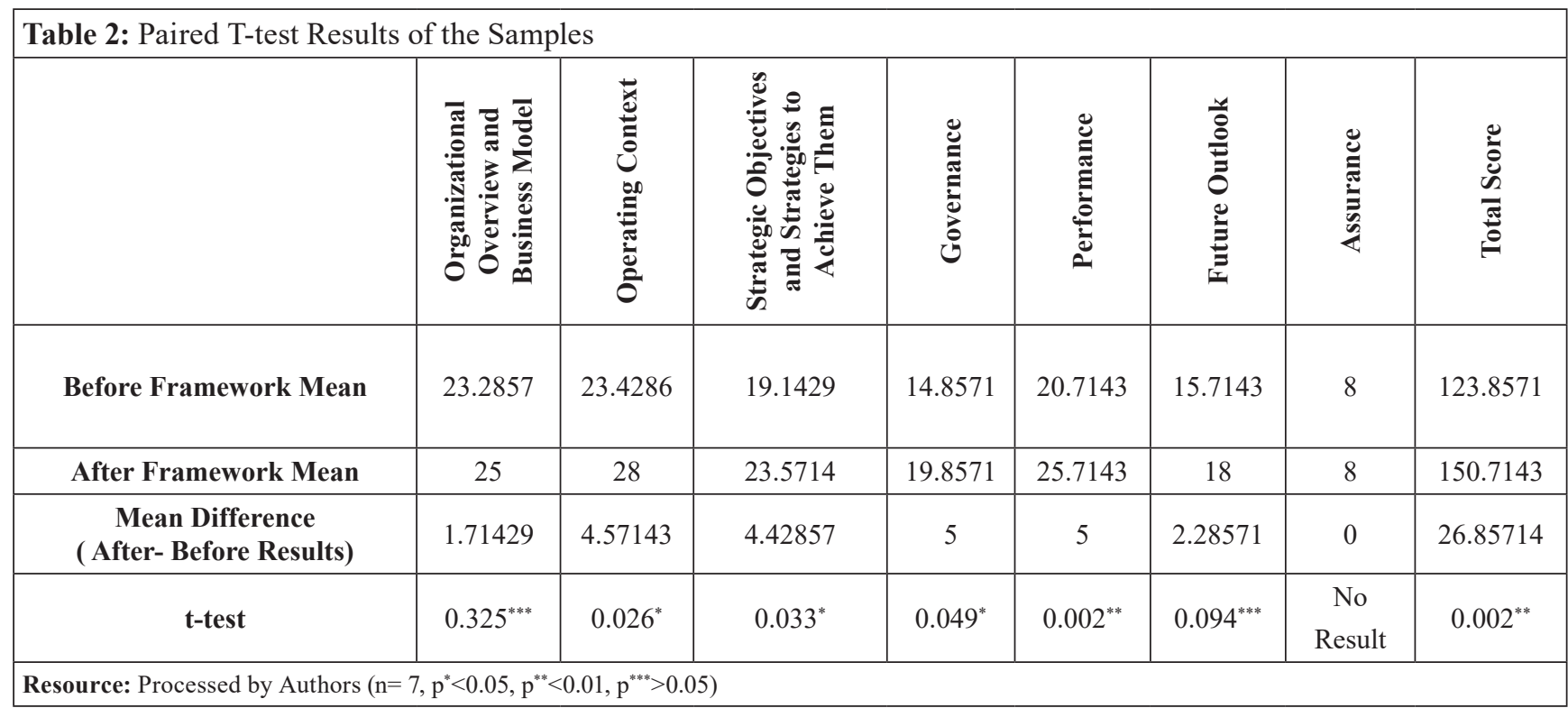

The T-test result is 0.026 , showing that the integrated reporting framework has influenced the "operating context" score of companies. The before framework score mean is 23.4286 , and the after framework score mean is 28 . The positive influence of the integrated reporting framework might be told. For "strategic objectives and strategies to achieve them", the t-test result is 0.033 , showing that the integrated reporting framework influenced the score of the "strategic objectives and strategies to achieve them" category.

The before framework average score is 19.1429 while after the framework score is 23.5714 . Differences between means are 4.42857. For "governance", the significance value of the t-test is 0.049 .The average score for before framework is 14.8571 , but the average governance score of the after framework is 19.8571. This shows the difference between score means is five points. The integrated reporting framework increased the governance score by 5 points. The zero hypothesis for the performance category is that the integrated reporting framework has no effect on the performance score of companies. One hypothesis is that the integrated reporting framework has an effect on the performance score of companies. The T-test result is 0.002 and the integrated reporting framework has an influence on the performance score of companies. The average score before framework is 20.7143 while the average score after framework is 25.7143 . The Zero hypothesis for future outlook is that the integrated reporting framework has no influence on the future outlook score of the companies. Hypothesis one is 
that the integrated reporting framework has an influence on the future outlook score of the companies. The T-test result is 0.094, and the integrated reporting framework has no influence on the future outlook score of the sample. For the assurance category, the integrated reporting framework has no influence on the "assurance" category of the corporate reports might be told. The mean score before and after framework is 8 points.

\section{Conclusion}

In this study, the compliance of shipping companies and their reports with the integrated reporting framework (IIRC, 2013) is analyzed. The compliance score of the sample companies rises steadily from 2010 to 2014 . On the other hand, the total score decreases in 2015 and 2016. The primary reason for the declines in 2015 and 2016 may be the efforts of the companies to make reports concise. This prevents a detailed explanation of all the information about the company. However, the total score rises again in 2017, and the compliance score of companies is significantly higher in the after framework period. The compliance score of the "future outlook", "performance", "governance", "strategical objectives and strategies to achieve them", "operating context" and "organizational overview and the business model" categories increase steadily within the period of 2010-2014. The T-test results also indicate that the compliance score of the "operating context", "strategical objectives and strategies to achieve them", "governance" and "performance" categories is higher in the after framework period.

Stent and Dowler (2015) put forward that existing reporting practices are inadequate with respect to the recognition of the future uncertainties required by the integrated reporting (Stent and Dowler, 2015: 92). The results of this study show that the compliance score of the future outlook category increases between the years 2010-2014. According to the t-test results, the "future outlook" score of companies does not change after the integrated reporting framework.

Previous suggestions for the "assurance" of integrated reporting is that there is no high level of assurance due to the lack of integrated reporting audit regulations (Oprisor, 2015: 93). The primary reason for that is the differences in the source of assurance (Burke and Clark, 2016: 278). At least some audit regulations are required for the wide application of integrated reporting (Maroun, 2017: 343).

For strategical aspects of integrated reporting, Mio et al (2016) assert that integrated reporting helps the improvement of strategy (Mio et al, 2016:216). The compliance score of "strategical objectives and strategies to achieve them" indicates a rise between the years 2010-2014, and the average compliance score of the after the integrated framework period is higher than the before the framework period. Increasing compliance score of this category with the integrated reporting framework enables companies to develop better strategies.

Regarding the contributions, the results of this study may be used by the shipping companies, regulators, and politicians for the development of the integrated reporting in the shipping companies by providing information on the current situation of integrated reporting in the shipping companies. This study also contributes to the literature by providing sectoral evidence.

Every research has limitations. The findings of this research may be extended by using more data. In this study, six of the seven companies used in the research are South Asian companies. Analyses of country-specific factors such as political, legal, financial, education and labour systems, cultural and economic dimensions, and their effects on the shipping companies' integrated reporting compliance are suggested for future research.

Peer-review: Externally peer-reviewed.

Conflict of Interest: The authors has no conflict of interest to declare.

Grant Support: The authors declared that this study has received no financial support.

Hakem Değerlendirmesi: Dış bağımsız.

Çıkar Çatışması: Yazarlar çıkar çatışması bildirmemiştir.

Finansal Destek: Yazarlar bu çalışma için finansal destek almadığını beyan etmiştir. 


\section{References}

Abeysekera, I. (2013). A template for integrated reporting. Journal of Intellectual Capital, 14(2), 227-245.

Atkins, J., \& Maroun, W. (2015). Integrated reporting in South Africa in 2012: Perspectives from South African institutional investors, Meditari Accountancy Research, 23(2), 197-221.

Bommel, K. (2014). Towards a legitimate compromise?: An exploration of integrated reporting in the Netherlands. Accounting, Auditing and Accountability Journal, 27(7), 1157-1189.

Brown, J., \& Dillard, J. (2014). Integrated reporting: On the need for broadening out and opening up. Accounting, Auditing and Accountability Journal, 27(7), 1120-1156.

Cheng, M., Green, W., Conradie, P., Konishi, N., \& Romi, A. (2014). The international integrated reporting kramework: Key issues and future research opportunities. Journal of International Financial Management and Accounting, 25(1), 90-119.

Havlováa, K. (2015). What integrated reporting changed: The case study of early. Procedia Economics and Finance, 34, $231-237$.

International Integrated Reporting Council. (2010). The structure of IIRC. Retrieved From: http://integratedreporting.org/the-iirc-2/ structure-of-the-iirc/.

International Integrated Reporting Council. (2011). Towards integrated reporting, communicating value in the 21st Century. Retrieved From: http://integratedreporting.org/wp-content/uploads/2011/09/IR-Discussion-Paper-2011_spreads.pdf.

International Integrated Reporting Council. (2012). Integrated reporting prototype framework. Retrieved From: http://integratedreporting. org/wp-content/uploads/2012/11/23.11.12-Prototype-Final.pdf. (30.06.2019).

International Integrated Reporting Council. (2013). International integrated reporting framework. Retrieved From: http:// integratedreporting.org/wp-content/uploads/2013/12/13-12-08-THE-INTERNATIONAL-IR-FRAMEWORK-2-1.pdf. (09.10.2018).

Jensen, J. C., \& Berg, N. (2012). Determinants of traditional sSustainability reporting versus integrated reporting: An institutionalist approach. Business Strategy and the Environment, 21(5), 299-316.

Ki-Moon, B. (2016). Maritime transport is 'Backbone of global trade and the global economy. United Nations. Retrieved From: https:// www.un.org/press/en/2016/sgsm18129.doc.htm.(23.06.2019).

Krzus, M. P. (2011). Integrated reporting: If not now, when?. Journal of International Accounting, 6 (6), $271-276$.

Kurochkina, I., Shuvalova, E., \& Novozhilova, J. (2017). About formation of the integrated reporting Performance in the process of building a sustainable business of transport and communication companies. Procedia Engineering, 178(2017), 267-277.

Maroun, W. (2017). Assuring the integrated report: Insights and recommendations from auditors and preparers. The British Accounting Review. 49(3), 329-346.

Maroun, W., \& Atkins, J. (2018).The emancipatory potential of extinction accounting: Exploring current practice in integrated reports. Accounting Forum, 42(1), 102-118.

Mc Vea, J. F., \& Freeman, R. E. (2005). A names-and-faces approach to stakeholder management how focusing on stakeholders as individuals can bring ethics and entrepreneurial strategy together. Journal of Management Inquiry. 14(1), 57-69.

Mio, C., Marco, F., \& Pauluzzo, R. (2016). Internal application of IR principles: Generali's internal integrated reporting. Journal of Cleaner Production, 139 (December), 204-218.

Oprisor, T. (2015). Auditing integrated reports: Are there solutions to this puzzle? Procedia Economics and Finance, 25(2015), 87-95.

Oral, T. (2018). Content analysis in integrated reporting. ( Unpublished doctoral dissertation). Malatya: İsmet İnönü University Graduate School of Social Sciences.

Sigalı, S., \& Kaytmaz Balsarı, Ç. (2018). Theoretical insights on integrated reporting and externalities. World of Accounting Science, 20( Special Issue), 859-869.

Stent, W., \& Dowler, T. (2015). Early assessments of the gap between integrated reporting and current corporate reporting. Meditari Accountancy Research, 23(1), 92-117. 
Steyn, M. (2014). Organisational benefits and implementation challenges of mandatory integrated reporting perspectives of senior executives at South African listed companies. Sustainability Accounting, Management and Policy Journal, 5(4), 476-503.

Stubbs, W., \& Higgins, C. (2014). Integrated reporting and internal mechanisms of change. Accounting, Auditing and Accountability Journal, 27(7), 1068-1089.

United Nations Conference on Trade and Development. (2018). Review of Maritime Transport 2018. Retrieved From: https:/unctad.org/ en/PublicationsLibrary/rmt2018_en.pdf. (12.07.2019).

Villiers, C., Rinaldi, L., \& Unerman, J. (2014). Integrated reporting: Insights, gaps and an agenda for future research. Accounting, Auditing and Accountability Journal, 27(7), 1042-1067.

De Villiers, C., \& Sharma, U. (2018). A critical reflection on the future of financial, intellectual capital, sustainability and integrated reporting. Critical Perspectives on Accounting, In press. (May 2017). Retrieved From: https://ac.els-cdn.com/S1045235417300606/1-s2.0S1045235417300606-main.pdf?_tid=d042d1b8-be9f-4b0c-b89e cc9f2dcd2b35andacdnat=1543236458_0c7b798c40d7c36054507d7b6f925a15. Y1lmaz, N. D. (2016). Analysis of integrated reporting from the standpoint of investors and algorithm of integrated investment analysis. (Unpublished master thesis). Kütahya: Dumlupınar University Graduate School of Social Sciences. 
